\title{
To network or not to network - Is that really the question? The impact of networking intensity and strategic orientations on innovation success
}

\author{
Fabian Eggers $^{\mathrm{a}, *}$, Thomas Niemand ${ }^{\mathrm{b}}$, Matthias Filser ${ }^{\mathrm{c}}$, Sascha Kraus ${ }^{\mathrm{d}}$, Jennifer Berchtold ${ }^{\mathrm{e}}$ \\ a Menlo College, 1000 El Camino Real, Atherton, CA 94027, USA \\ ${ }^{\mathrm{b}}$ Clausthal University of Technology, Department of Market Research, Albrecht-von-Groddeck-Straße 7, 38678 Clausthal-Zellerfeld, Germany \\ c University of Liechtenstein, Institute for Entrepreneurship, Fürst-Franz-Josef-Strasse, 9490 Vaduz, Liechtenstein \\ d École Supérieure du Commerce Extérieur, ESCE International Business School, 10 rue Sextius Michel, 75015 Paris, France \\ e Lappeenranta University of Technology, Skinnarilankatu 34, 53850 Lappeenranta, Finland
}

A R T I C L E I N F O

\section{Keywords:}

Innovation success

Strategic orientations

Networking

\begin{abstract}
A B S T R A C T
Innovation success typically leads to company success. That is, firms that successfully create and launch innovations often grow in terms of revenues, profits, and head count. Societies benefit not only from new products and services, but also from new jobs, as created through innovating firms. Thus, innovation success potentially leads to increased societal wealth. However, the question arises: What factors help companies to become successful innovators? Research shows that networking activities between firms and their stakeholders have an important impact on innovation success. This is particularly true for small and medium enterprises (SMEs) that often lack crucial resources that enable them to innovate. However, a few existing studies do not support the finding that networking leads to increased innovation outputs. So, we must ask: Under which circumstances do networking activities enable SMEs to become successful innovators? In this study, we analyze a sample of 451 SMEs and, using fuzzy set Qualitative Comparative Analysis (fsQCA), find that the question is not whether to network or not. Rather, both high- and low-intensity networking firms can use different combinations of underlying strategic orientations and resource-leveraging capabilities to enable innovation success.
\end{abstract}

\section{Introduction}

A key capability of thriving companies is their ability to launch innovations successfully. Innovation success-i.e., the tangible outcome of the innovation process in terms of product innovation (e.g., new product or service development); process innovation; or, organizational innovation (e.g., implementation of new methods to increase administrative efficiency)-is crucial because it is thought to increase firm performance (Baker and Sinkula, 2009; Rogers, 2004). Also, innovation is given credit for driving employment and growth, thus also playing a crucial role in creating wealth and enhancing living standards (OECD, 2010). Freeman and Soete (1997, p. 266) even claim that "[...] not to innovate is to die." This is particularly true for smaller firms that are forced to innovate to survive and achieve business success (Heunks, 1998). However, SMEs tend not to possess the essential resources, competencies, and knowledge to generate innovation outputs. Lacking these crucial resources, SMEs are often unable to innovate on their own (Freel, 2003). Especially, smaller firms are dependent on external knowledge networks (Rogers, 2004). In this regard, resources from outside the company play a decisive role (Cohen and Levinthal, 1990).

Several research studies have demonstrated the importance of networks in improving innovation outcomes (Gronum et al., 2012). Gemünden et al. (1992, p. 373) point out that firms "which do not supplement their internal resources and competence with complementary external resources and knowledge show a lower capability for realizing innovations." Therefore, the absence of networking activities may lead to limited knowledge bases, which in turn result in lower rates of innovation success. Love and Roper (1999) suggest that network intensity (i.e., the number of external network contacts and the frequency of interaction with them) has a positive impact on the innovation output; whereas Gemünden et al. (1996) highlight that networking leads to an increase in product improvements and development of new innovations. Furthermore, networking activities facilitate innovation success in terms of economical relevance and technical realization (Gemünden et al., 1992). Due to networking behavior, these innovation outputs are boosted and firms become more competitive (Ahuja, 2000; Powell et al., 1996).

Most studies suggest a positive relationship between networking

\footnotetext{
* Corresponding author.

E-mail address: fabian.eggers@menlo.edu (F. Eggers).
}

This accepted manuscript is licensed under a Creative Commons AttributionNonCommercial-NoDerivatives 4.0 International License. 
and the innovation process (e.g., Eggers et al., 2014; Love and Roper, 1999; Ragatz et al., 1997; Ritter and Gemünden, 2003); however, a few do not fully support these findings and point out that downsides in terms of networking activities exist as well (e.g., Alguezaui and Filieri, 2010; Arias, 1995; Harris et al., 2000). Arias (1995) indicates that close relationships with network partners might impede the innovation process and can, therefore, have a negative impact on a firm's innovation performance. A possible explanation for this negative effect is that networks make decision processes more complex, interfering with a firm's independence; this could result in a loss of control and lead to information imbalances (Hagedoorn, 1995). Especially, smaller firms that collaborate with larger firms run the risk of being controlled by the larger and more powerful company (Garnsey and Wilkinson, 1994).

Thus, SMEs face pros and cons when it comes to establishing network relationships to boost innovation success. Therefore, it seems worthwhile to investigate various underlying factors that enable innovation success in firms with different networking intensities. This study focuses on strategic orientations-namely, entrepreneurial orientation (EO), customer orientation (CO), market driving (MD), social orientation (SO), and resource-leveraging (RL) capabilities-and uses fuzzy set qualitative comparative analysis (fsQCA) to analyze how strategic orientations and the ability to leverage resources affect innovation success. By doing so, this study aims to reveal certain combinations that explain innovation success in firms that network with more intensity (Networkers) as compared to SMEs that network with less (Solitudes).

\section{Determinants of innovation success}

\subsection{Entrepreneurial orientation}

According to Miller (1983, p. 771) the "entrepreneurial firm is one that engages in product-market innovation, undertakes somewhat risky ventures, and is first to come up with "proactive" innovations, beating competitors to the punch." As highlighted by Wales et al. (2013), as well as Rauch et al. (2009), the majority of studies use Miller's (1983) three-dimensional conceptualization: 1) Innovativeness, 2) Proactiveness, and 3) Risk-Taking. Innovativeness is defined as "[...] a firm's tendency to engage in and support new ideas, novelty, experimentation, and creative processes that can result in new products, services, or technological processes" (Lumpkin and Dess, 1996, p. 142). Thus, innovativeness is an important resource of EO, necessary to pursue new opportunities (Semrau et al., 2016). Proactiveness can be described as an opportunity-seeking, prospective behavior to anticipate future demand. Proactive firms continuously search for new business opportunities to assure future profit streams (Rigtering et al., 2014). Risk-taking is characterized by " $[\ldots]$ the degree to which managers are willing to make large and risky resource commitments-i.e., those that have a reasonable chance of costly failure" (Miller and Friesen, 1978, p. 923).

In fact, EO can be viewed as a strategic dimension on which every firm can be mapped (Covin and Slevin, 1991). Every company exhibits a certain level of innovativeness, proactiveness, and risk-taking, even if these companies are positioned at the rather low end of the spectrum (Anderson et al., 2015; Covin and Wales, 2012; Schindehutte et al., 2008). However, numerous studies have demonstrated that companies with a high level of EO perform significantly better than firms that exhibit a low level of EO (for an overview, see Rauch et al., 2009). Due to the need to search actively for new business opportunities, the adoption of EO may be beneficial to companies that want to drive markets and gain a competitive advantage (Wiklund and Shepherd, 2005; Zortea-Johnston et al., 2012).

According to Schindehutte et al. (2008, p. 14), "innovation is an important result of ... EO." Consequently, firms with higher levels of EO generate innovation outputs that are disruptive rather than incremental. Also, Zortea-Johnston et al. (2012) find that companies with high levels of EO stimulate innovation outcomes that are both incremental and disruptive. In this regard, the implementation of an EO may be advantageous and support firms to produce innovation outputs that can range from incremental to radical.

At the same time, Walter et al. (2006, p. 542) state that "[f]irms should note that an entrepreneurial orientation in and of itself is not enough to compete in today's markets. EO is an entrance ticket that allows for higher impacts of competencies on performance," explicitly noting the importance of networking activities. According to Walter et al. (2006), networking activities should be combined with an EO to be successful. Due to the information benefits, networking firms more easily identify and exploit new entrepreneurial opportunities (Lee et al., 2001). Furthermore, the reconfiguration of strengths and competencies by means of networks can be of high importance for the identification of new opportunities (Frenken, 2000).

All in all, EO can be considered an essential and extensive strategic orientation that can lead to innovation success. In this respect, it is assumed that EO plays a vital role in achieving innovation success for both high- and low-intensity networking SMEs.

\subsection{Customer orientation}

Various terms are used to describe the concept of $\mathrm{CO}$, such as responsive market orientation (e.g., Narver et al., 2004), customer-led business (e.g., Slater and Narver, 1998), customer-compelled business (e.g., Day, 1999), or responsive market-driven behavior (Jaworski et al., 2000). Confusion arises due to its similarity to the concept of market orientation (MO). CO refers to the identification and satisfaction of customers' expressed needs; whereas MO considers both the expressed and latent needs of customers. In this regard, responsiveness and proactiveness form the basis of MO (Narver et al., 2004). However, CO consists of only one of the aforementioned dimensions-namely, responsiveness, i.e., the ability to respond to customers' articulated wishes and provide favored offerings in served markets (Verhees and Meulenberg, 2004). Hence, the aim of customer-oriented businesses is to uncover and understand customers' expressed needs, and to develop products and services that satisfy those needs (Slater and Narver, 1998).

Due to the sole satisfaction of expressed customer needs, CO has a short-term perspective. According to Christensen and Bower (1996, p. 198), "firms lose their position of industry leadership...because they listen too carefully to their customers." Hamel and Prahalad (1994) name this phenomenon tyranny of the served market, which refers to the overriding focus on their customers' point of view. As a result, firms ignore ongoing changes in the market. A customer-led philosophy leads to success in stable and foreseeable environments, but can be risky in turbulent environments (Slater and Narver, 1998). Due to fast-changing conditions, such as accelerated product and business model lifecycles, unstable financial markets, and the growing and turbulent world economy, prospective profit streams solely from a CO are questionable (Berthon et al., 1999). Consequently, CO typically results in innovation outputs that are incremental in nature, such as improvements of existing product and service efforts (e.g., Baker and Sinkula, 2009; Pittaway et al., 2004; Schindehutte et al., 2008; Zortea-Johnston et al., 2012).

At the same time, customers play a central role in innovation processes. Gemünden et al. (1992) point out that $75 \%$ of firms integrate their customers into the innovation process; and half of these companies consider customer engagement to be a requirement for innovation success. Research highlights the importance of engagement with customers, as it can help identify and generate ideas that are valuable for the innovation process (Ragatz et al., 1997; Von Hippel, 1978). However, isolated customer interaction may not produce sufficient results when aiming to generate product innovations. Rather, networking with various customers and other partners is key (Gemünden et al., 1996). In this regard, Eggers et al. (2014) investigate the link between networking and a firm's innovativeness, finding that lower intensity networking firms achieve greater levels of innovativeness than higher 
intensity networking firms when emphasizing high levels of CO.

Overall, it can be assumed that $\mathrm{CO}$ has a positive effect on innovation success in SMEs. In lower intensity networking firms, CO can be particularly useful to compensate for lacking relationships with other partners.

\subsection{Market driving}

According to Jaworski et al. (2000, p. 45), a market-driving approach "implies influencing the structure of the market and/or the behavior(s) of market players in a direction that enhances the competitive position of the business." As highlighted in their definition, the authors propose a conceptual framework that consists of two dimensions: market structure and market behavior. In contrast to marketdriven businesses that focus solely on the customer, market drivers regard all partners in the entire value chain as important stakeholders (Schindehutte et al., 2008) and proactively aim to shape the composition and behavior of the players to achieve a competitive advantage (Jaworski et al., 2000).

A lively debate surrounds the interplay between the market-driven and the market-driving approaches (Schindehutte et al., 2008). Jaworski et al. (2000) hold that they complement one another. Therefore, a company need not decide on one approach; on the contrary, it can pursue a market-driving strategy and a market-driven approach simultaneously. Abell (1993) calls the coexistence of these two approaches a dual strategy. Such a dual strategy can be seen in companies that exploit their old technologies and concomitantly attempt to explore and develop new technological alternatives for future demands (Jaworski et al., 2000). On the contrary, Carpenter et al. (2001) highlight that market-driven and market-driving are substitutes. This means that a company must choose only one approach. Kumar et al. (2000) argue that a market-driven company can switch to a market-driving approach or vice versa. Johnson et al. (2003) regard both approaches as extreme points on the spectrum. This means that market-driven firms are plotted at the lower end of the continuum, and market-driving companies are at the higher end.

Schindehutte et al. (2008, p. 21) highlight that "the emergence of market-driving behavior is the essence of entrepreneurial action in the Schumpeterian 'creative destruction' sense." Market drivers are disruptive innovators that develop innovation outputs with higher speed and frequency. Therefore, market driving serves as an important prerequisite for the achievement and preservation of sustainable competitive advantages.

Jaworski et al. (2000) point out that market drivers are able to transform the market structure through the addition of further players into the value chain (construction), the elimination of other market players from the present value chain (deconstruction), and shifting the functions of the market players (functional modification). Furthermore, such companies are also able to change the behavior of crucial actors, such as customers or competitors, in direct and indirect ways. Therefore, market-driving companies often network with key actors to educate, control, and, ultimately, change their behaviors.

A market-driving approach can be appropriate for both large firms and SMEs. Large companies typically possess the resources needed to shape market structure and behavior (Jaworski et al., 2000). SMEs, on the other hand, must rely on networks to gain access to the resources necessary to drive markets.

\subsection{Social orientation}

The core of most existing definitions of SO is related to the implementation of social activities to solve social problems (Halberstadt and Kraus, 2016). Thus, not surprisingly, various areas are crucial in the context of socially oriented firms, such as environmental, community and governance performance (Crucke and Decramer, 2016). For this study, we define SO as a concept consisting of two main elements: responsibility for the community and responsibility for the environment. Whereas the former focuses on the firm being mindful about its community impact, which includes the employment of socially disadvantaged people (Crucke and Decramer, 2016), the latter deals with protecting the environment through "organizational greening behavior" (Andersson et al., 2013).

SO enables firms to discover socially relevant opportunities inside and outside the company and to innovate in these areas. Thus, an objective of SO firms is concerned with the execution of "innovative activities and services that are motivated by the goal of meeting a social need and that are predominantly diffused through organizations whose primary purposes are social" (Mulgan et al., 2007, p. 8). At the same time, SO is not only found in governmental and non-profit-making organizations (Sharir and Lerner, 2006), but also in social-mission-oriented, for-profit firms (Robinson, 2006).

Shaw and Carter (2007) examine social firms and find that networks play a crucial role in gaining access to important knowledge and information that can result in the identification of unmet social needs. Furthermore, the culture of social enterprises facilitates entrepreneurial activities, which in turn lead to innovations. Leadbeater (1997) points out that socially oriented companies identify under-utilized resources like people and equipment and find ways to put them to use to satisfy unmet social needs.

Therefore, to increase the innovation output, it can be assumed that SO is particularly useful in high intensity networking SMEs.

\subsection{Resource leveraging}

The possession of valuable, inimitable, rare, and unique resources is essential, but insufficient to create value and gain competitive advantage (Sirmon et al., 2007). Therefore, resources must be strategically applied and ideally leveraged to innovate successfully. RL represents an attitude referred to as "doing more with less" (Morris et al., 2002, p. 7). According to Morris et al. (2002), RL includes working with resources that are currently controlled, utilizing specific resources to gain other resources, combining complementary resources to create more value, stretching resources, and using resources from other firms. Regarding the latter, the capability to leverage resources enables a firm to work with resources not currently controlled. These resources are typically obtained through networks.

Wilson and Appiah-Kubi (2002) examined the role of the internal and external resources of 65 high-technology entrepreneurial firms in New Zealand, finding that RL via external networks is a vital source of firm growth. Successfully combining internal and external firm resources improves firm performance (Wilson and Appiah-Kubi, 2002). This finding is in accordance with Jarillo (1989), who points out that networking activities represent a way to gain access to essential resources that reside outside the company's control. Furthermore, entrepreneurial firms that use networks to introduce resources from outside the company grow at faster rates than firms that network less and do less resource-leveraging.

Thus, RL is important to the ability to innovate successfully, especially in high intensity networking SMEs.

\subsection{Relative importance of networking}

Overall, it can be assumed that strong networking activities benefit most strategic orientations and the ability to leverage resources. However, CO is considered to offer specific advantages in lower-intensity networking firms. Also, it is likely that interaction effects between these variables enable innovation success in both low- and highintensity networking companies.

Baker and Sinkula (2009) and Walter et al. (2006) stress that firms should not focus solely on EO in their innovation efforts. Baker and Sinkula (2009) find that firms with high levels of EO but without customer focus possess the ability to identify new market opportunities, 
but they cannot reasonably focus on those opportunities with the greatest chance of success. Therefore, innovation efforts of EO firms without a strong CO may result in innovation outcomes that are irrelevant to the customer (Baker and Sinkula, 2009). In addition, a strong correlation typically exists between EO and MD (Schindehutte et al., 2008). Zortea-Johnston et al. (2012, p. 156) highlight that "firms with an entrepreneurial orientation not only create new markets or re-arrange existing ones by launching new products or services, but also cause customers to alter their usage behavior." According to Leadbeater (1997), social entrepreneurs are a crucial source to generate innovations-that is, a high level of EO is needed to unleash the innovation potential of SO. Finally, leveraging resources can be a proactive, innovative, and even risk-taking endeavor, which also calls for high levels of EO.

A high level of CO, when not combined with other strategic orientations, should be treated with caution (Slater and Narver, 1998). Whereas the interplay of $\mathrm{CO}$ and EO in innovation efforts has been discussed above, it can be noted that $\mathrm{CO}$ and $\mathrm{SO}$ have the potential to complement each other as well. Finding and meeting social needs (Mulgan et al., 2007) go along with having close contacts with the company's stakeholders, with its customers being an important group. Also, a close connection exists between CO and RL, manifested in the concept of bootstrapping. Bootstrapping is about a firm's effort to develop resources on the go, e.g., a lack of financial resources can be overcome by generating instant revenues, which in turn requires a strong customer focus (Bhidé, 2000). From an innovation standpoint, close customer contacts can provide the firm with knowledge resources that help develop and execute new ideas.

\section{Methodology}

\subsection{QCA approach}

To close the present research gap, traditional and alternative empirical analyses are available. Traditionally, regressions, linear models, and variants thereof (e.g., structural equation modeling) are applicable for testing underlying hypotheses. Alternatively, qualitative comparative analyses (QCA) can be used to assess propositions (Ragin, 2008; Kraus et al., 2018). We chose QCA for three major reasons. First, regression analyses routinely fail to address theory testing adequately (e.g., Woodside, 2013), as these analyses are based on the net effects of the estimated variables. That is, a majority compared to a minority of values provides a certain sign (e.g., mainly positive). This often contradicts a theory where a positive sign is expected in some cases while a negative is assumed in others. Hence, conditions of multiple variables (configurations, hereafter termed "paths") are more plausible. Our propositions match with this configurational approach (Covin et al., 2016). Second, originally developed for presence-non presence, dichotomous empirical data, the newly advanced fuzzy set QCA (fsQCA) explicitly allows us to account for the continuous nature of firm-level variables upon which entrepreneurial research relies so heavily (e.g., Thiem and Dusa, 2013; Wagemann and Schneider, 2010). As present, research deals with rather latent indications of firm-wide orientations-for example, EO (Covin and Lumpkin, 2011)—the nature of our data will be more continuous than binary, allowing fsQCA to overcome the net effect weakness of regressions while accounting for the present nature of the data. Third, and according to our propositions, innovation success is understood as the dependent (regression terminology) or outcome (QCA terminology) variable. QCA hereby allows a rather direct and more "managerial" interpretation of the outcome: Either innovation success is achieved or it is not, without introducing a thinking of probability or certainty that may limit implications due to misunderstandings of inferential statistics or overly simplifying regression estimates (e.g., Skarmeas et al., 2014; Woodside, 2013). To ensure methodological quality of the present QCA, state-of-the-art guidelines are used to obtain the fuzzy sets (e.g., Thiem and Dusa, 2013;
Wagemann and Schneider, 2010) and quantiles of 0.05, 0.33, 0.50, 0.66 , and 0.95 are used to represent a wide range of non-membership (no innovation success) to full membership (innovation success). Further, and in line with those guidelines, only consistent and unique conditions will be provided. Consistency $\geq 0.75$ means the same outcome is found for a certain condition in three out of four cases. And unique coverage $\geq 0.01$ indicates that all conditions explain something novel. Optimization and estimation were conducted via QCApro (Thiem and Dusa, 2013).

As proposed before, networking intensity is assumed to work as a grouping variable that alters the principal causal relationships between the present variables and innovation success (in regression terms, a moderator). However, QCA does not allow for this type of relationship. Thus, we used a proportional split as a variant of a median split (both are equal for a proportion of 0.5 ) following the recommendations of DeCoster et al. (2009) to simplify networking intensity as an originally continuous variable into two groups: low intensity networking firms $(\mathrm{n}=209)$ and high intensity networking firms $(\mathrm{n}=242)$ with a split value of -0.02 . This means that more firms indicated networking than not.

\subsection{Measures}

Due to the scope of the present work, all variables are rather latent and firm-level, requiring a key respondent-based data collection. We applied established measures and a consistent 5-point Likert scale ( $1=$ totally disagree to $5=$ totally agree, except the dependent variable) throughout the questionnaire. All scales were reliable in terms of Cronbach's Alpha (CA > 0.7) and represented the dimensions they were intended to measure (Kline, 2015). Table 1 provides all item wordings. EO was measured via 14 items representing innovativeness ( 5 items, CA $=0.84$ ), risk-taking ( 4 items, $\mathrm{CA}=0.75$ ), and proactiveness ( 5 items, CA $=0.79$ ) using the scale proposed by Eggers et al. (2013). CO is assessed via the responsive marketing orientation dimension of Narver et al. (2004) consisting of 7 items (CA $=0.81$ ). SO is based on 6 items $(C A=0.80)$ following Miles et al. (2014) and Kraus et al. (2017). MD is based on the version of Stolper (2007) consisting of 4 items $(C A=0.82)$ and $R L$ was measured using 2 items $(C A=0.76)$ based on Morris et al. (2002). Networking intensity is captured through 3 items (CA $=0.83$ ) adapted from Ostgaard and Birley, (1994). Finally, the outcome of innovation success was adapted from Baker and Sinkula (2009) and measured with 4 items $(C A=0.93)$. All items were first translated to German and then translated back to English by two independent researchers.

\subsection{Sample}

To conduct the empirical study, a large-scale sample was selected from the Austrian company database AURELIA. Hereby, only higherlevel executives and managers were considered in a key informant approach. These managers were invited via personalized e-mails; and, if they chose to participate, they were redirected to an online German language questionnaire. After checking responses for consistency and completeness for the QCA technique, a final sample of 451 key firm executives remained. Next, a possible non-response bias was checked for all measures applied in the QCA on an item-based level using a variant of the procedure by Armstrong and Overton (1977). Averages from pairwise $t$-tests for equally large quantiles of early-to-respond informants for each item showed no indication of a systematic non-response pattern (no significant differences). Hence, early and late respondents did not differ in their evaluation of the investigated constructs.

The sample consisted of mostly male executives $(77.4 \%, \mathrm{n}=349)$ with a mean age of 49.2 years ( $S D=10.3,20-79$ years' range) and a diverse educational background (Top 3: $34.8 \%, \mathrm{n}=157$ : university degree; $23.1 \%, \mathrm{n}=104$ : school leaving examination; $12.6 \%, \mathrm{n}=57$ : 
Table 1

Measures for latent variables.

\begin{tabular}{|c|c|c|}
\hline Latent variable & Label & Item \\
\hline \multirow[t]{5}{*}{ Innovativeness } & IN1 & When it comes to problem solving, we value creative new solutions more than solutions that rely on conventional wisdom. \\
\hline & IN2 & We highly value new product lines. \\
\hline & IN3 & We consider ourselves to be an innovative company. \\
\hline & IN4 & Our business is often the first to market with new products and services. \\
\hline & IN5 & Competitors in this market recognize us as leaders in innovation. \\
\hline \multirow[t]{4}{*}{ Risk-taking } & RT1 & We value new strategies/plans even if we are not always certain they will work. \\
\hline & RT2 & To make effective changes to our offering, we are willing to accept at least a moderate level of risk of significant losses. \\
\hline & RT3 & We encourage people in our company to take risks with new ideas. \\
\hline & RT4 & We engage in risky investments (e.g., new employees, facilities, debt, stock options) to stimulate future growth. \\
\hline \multirow[t]{5}{*}{ Proactiveness } & PA1 & We continuously try to discover additional customer needs of which our customers yet are unaware. \\
\hline & PA2 & We consistently look for new business opportunities. \\
\hline & PA3 & Our marketing efforts try to lead customers rather than responding to them. \\
\hline & PA4 & We incorporate solutions to unarticulated customer needs in our products and services. \\
\hline & PA5 & We work to find new businesses or markets to target. \\
\hline \multirow[t]{7}{*}{ Customer orientation } & $\mathrm{CO} 1$ & We constantly monitor our level of commitment and orientation to serving customer needs. \\
\hline & $\mathrm{CO} 2$ & We freely communicate information about our successful and unsuccessful customer experiences across all business functions. \\
\hline & $\mathrm{CO} 3$ & Our strategy for competitive advantage is based on our understanding of customers' needs. \\
\hline & $\mathrm{CO} 4$ & We measure customer satisfaction systematically and frequently. \\
\hline & $\operatorname{co5}$ & We are more customer-focused than our competitors. \\
\hline & CO6 & We believe this business exists primarily to serve customers. \\
\hline & $\mathrm{CO} 7$ & Data on customer satisfaction is disseminated at all levels of this business unit on a regular basis. \\
\hline \multirow[t]{6}{*}{ Social orientation } & SO1 & The objective to accomplish our social mission precedes the objective to generate a profit. \\
\hline & $\mathrm{SO} 2$ & $\begin{array}{l}\text { Our organization places a strong focus on partnerships with other organizations and/or governments to ensure a greater and accelerated } \\
\text { accomplishment of the social mission. }\end{array}$ \\
\hline & SO3 & We measure $\mathrm{CO} 2$ emissions and/or our generated waste and actively try to reduce it. \\
\hline & SO4 & We set ambitious goals for ourselves regarding sustainability and incorporate them in all strategic decisions. \\
\hline & SO5 & We actively employ socially disadvantaged people (e.g., disabled people, immigrants, and the elderly). \\
\hline & SO6 & We support and encourage our employees to become active in voluntary commitments outside of our organization to address social issues. \\
\hline \multirow[t]{4}{*}{ Market driving } & MD1 & We always try to develop new products that should challenge our customers to rethink their purchasing behaviors. \\
\hline & MD2 & We are market pioneers and act on the assumption that consumers and competitors follow us. \\
\hline & MD3 & We consistently pick up ideas from other industries to surprise our customers and competitors. \\
\hline & MD4 & We consistently develop new, spectacular marketing concepts, which our competitors imitate. \\
\hline \multirow[t]{2}{*}{ Resource leveraging } & RL1 & We arrange with other companies to refer each other to save on marketing costs. \\
\hline & RL2 & We use connections to other companies to increase our offerings in cost-efficient ways. \\
\hline \multirow[t]{3}{*}{ Network intensity } & NI1 & We exchange regularly with our network partners. \\
\hline & NI2 & We like to keep a close relationship with our network partners. \\
\hline & NI3 & There is informal exchange between our network partners and us. \\
\hline \multirow[t]{4}{*}{ Innovation success } & IS1 & Our rate of innovation compared to that of our direct competitors is ... (very low to very high). \\
\hline & IS2 & The level of differentiation between our innovations and those of our direct competitors is ... (very low to very high). \\
\hline & IS3 & The rate at which we outperform our direct competitors in innovations is ... (very low to very high). \\
\hline & IS4 & The frequency of our innovations as compared to those of our direct competitors is ... (very low to very high), \\
\hline
\end{tabular}

teacher training). $86.3 \%$ of the respondents were the CEOs of their firms $(n=389)$. From a corporate perspective, these managers represented firms with a mean age of 29.4 years (SD $=36.2,1-378$ years' range) that are predominantly small ( $<30$ employees: $72.9 \%, \mathrm{n}=329$; 31-100 employees: $15.1 \%, \mathrm{n}=68 ; 101-250$ employees: $12.0 \%$, $\mathrm{n}=54)$, commercial $(89.8 \%, \mathrm{n}=405)$, and tertiary $(74.9 \%, \mathrm{n}=338)$.

\section{Results}

\subsection{Overview}

To facilitate comprehension, Table 2 provides an overview of the QCA results extracted from the optimization of the outcome from a truth table via the enhanced Quine and McCluskey algorithm (Thiem and Dusa, 2013). QCA terminology is somewhat (and intentionally) different from traditional regression (Ragin, 2008). Thus, we briefly explain the main concepts depicted. Present orientations can be

Table 2

Paths for solitudes and networkers.

\begin{tabular}{|c|c|c|c|c|c|c|c|}
\hline \multirow[b]{2}{*}{ Solution } & \multicolumn{3}{|c|}{$\begin{array}{l}\text { Solitudes } \\
\text { (low intensity networking) } \\
\text { Sample size }=209\end{array}$} & \multicolumn{4}{|c|}{$\begin{array}{l}\text { Networkers } \\
\text { (high intensity networking) } \\
\text { Sample size }=242\end{array}$} \\
\hline & $I$ & II & III & $I V$ & V & $V I$ & VII \\
\hline Entrepreneurial orientation & - & - & & - & ○ & • & - \\
\hline Customer orientation & $\bullet$ & & & & & - & - \\
\hline Social orientation & & $\bullet$ & - & & $\bullet$ & & 0 \\
\hline Market driving & - & - & $\bullet$ & - & - & $\bullet$ & \\
\hline Resource leveraging & 0 & & $\bullet$ & 0 & & & 0 \\
\hline Consistency & 0.822 & 0.813 & 0.756 & 0.806 & 0.821 & 0.816 & 0.746 \\
\hline Coverage & 0.408 & 0.413 & 0.340 & 0.470 & 0.501 & 0.534 & 0.428 \\
\hline Unique coverage & 0.075 & 0.017 & 0.036 & 0.026 & 0.026 & 0.011 & 0.036 \\
\hline
\end{tabular}


understood as requirements to achieve the desired outcome (innovation success in this case). Put simply, innovation can be successful only if they are present. By contrast, absence conditions can be understood as the lack of a variable. For example, a solution as the combination of conditions relevant to explain an outcome that has an absence condition explains what other variables need to be present to overcome the lack of the absent variable. Intuitively, blank conditions are irrelevant. Moreover, consistency indicates the reliability of a solution-that is, how often a certain combination of conditions yields the intended outcome divided by the number of all cases for that solution. A consistency of 1 would imply that the present, absent, and irrelevant conditions in one solution always yield the outcome of innovation success. Coverage instead equals the r-squared from regression, capturing to what extent a certain solution can explain all variations in the outcome. By the same token, unique coverage introduces a concept of an incremental contribution. Only solutions with positive unique coverage can explain "something new" in the outcome that cannot be explained by other solutions.

Subsequently, all solutions are interpreted as paths to be successful in developing innovations either for low-intensity networking firms (termed Solitudes) or high-intensity networking firms (Networkers).

\subsection{Paths for low-intensity networking firms (solitudes)}

Initially, the first path (I) shows that firms that network less and do little or no resource-leveraging can overcome these deficiencies by being entrepreneurial, customer-oriented, market-driven. Being socially oriented is irrelevant for this type of firm. This solution is highly consistent $(0.822)$ and has substantial coverage $(0.408)$ and unique coverage (0.075). Alternatively, the next path (II) shows that socially oriented Solitudes can achieve innovation success by incorporating EO and MD. RL and CO are minor. Like Path I, Path II is highly consistent (0.813) and explanatory (0.413 and 0.017). Finally, the third path (III) indicates an alternative path for lower-intensity networking firms to achieve innovation success by being socially oriented, market-driven, and resource-leveraging. In this case, EO and CO are irrelevant for success. Again, Path III yields sufficient consistency (0.756) and coverage $(0.340$ and 0.036$)$. A common theme of these Solitudes is obviously $\mathrm{MD}$, as it is present in all three paths.

\subsection{Paths for high-intensity networking firms (networkers)}

Among high-intensity networking firms, and in contrast to low-intensity networking firms, EO is consistently found in four paths to innovation success. First, Path IV shows that firms that are "frugal" in terms of RL can be successful by incorporating EO, MD, and RL. CO or SO are dispensable. Again, this path is highly consistent (0.806) and explanatory (0.470 and 0.026). Further, Path V and Path VI indicate alternative recipes of combining $\mathrm{EO}$ and $\mathrm{MD}$ with either SO (V) or CO (VI). In each case, the other orientation loses its impact upon innovation, as does RL in both solutions. Both paths are equally consistent (0.821 and 0.816$)$ and predict the outcome well ( 0.501 and 0.026 vs 0.534 and 0.011 ). Eventually, Path VII illustrates a solution for overcoming a lack of thrift (RL) and socialness (SO). In this case, entrepreneurial and customer-oriented Networkers are still successful on a corporate level. This path also negates the previous findings by removing the requirement of MD. However, consistency is quite below the other paths for high-intensity networking firms (0.746). Despite that, we decided to stay with this path due to its unique contribution, both from the QCA perspective (unique coverage: 0.036 ) and the qualitative content.

\section{Discussion and conclusion}

\subsection{Observed paths and their implications}

In contrast to earlier research, which suggests that networking is a prerequisite for innovation success, especially in the case of SMEs, this study clearly demonstrates that the issue is not about whether to network or not, because Solitudes and Networkers both possess the potential to promote innovation outputs. However, a combination of different underlying strategic orientations and resource-leveraging capabilities is required to facilitate innovation success. Therefore, the following typology of innovation success can be derived from our findings:

- Social Innovators (paths II and V): Entrepreneurially oriented firms, which also exhibit SO and MD, can be found among both Networkers and Solitudes. The combination of these strategic orientations contributes to the achievement of innovation success. Both CO and RL capabilities are irrelevant for these firms.

- Adaptive Market Shapers (path I): These Solitudes are trying to compensate for their lack of RL capabilities with a focus on EO and responsive behaviors ( $\mathrm{CO}$ and $\mathrm{MD}$ ) aiming to shape the market structure and the behavior of market players in the absence of SO. These firms not only satisfy customers' expressed needs, but also try to identify new business opportunities by uncovering customers' latent needs. These firms demonstrate that an SME can be both MD and market-driven, as proposed by Jaworski et al. (2000). This path supports the view that these strategic orientations can be executed simultaneously and complement each other in a positive way to promote innovation success.

- Thrifty Social Market Drivers (path III): Here, SO and MD are combined with the ability to leverage resources, which leads to innovation success. Socially oriented SMEs with an MD approach possess the ability to identify socially important opportunities that can change the rules of the game. Interestingly, EO and CO do not play a role for these firms.

- Thrifty Market Drivers (path IV): These networking SMEs combine EO with MD and the ability to leverage resources. $\mathrm{CO}$ and SO do not play a role in these firms.

- Customer-led Innovators (path VI): Networking SMEs balance their EO with CO to drive markets. SO and RL do not have an impact in these firms.

- Cocky Innovators (path VII): Here, entrepreneurially oriented SMEs are simultaneously customer-focused. Whereas MD does not play a role for these companies, a lack of social awareness and RL lead to innovation success.

The results reveal insights about the importance of EO, CO, MD, SO, and RL in boosting innovation success. Each construct can be found in the paths for both Networkers and Solitudes; thus, our assumption that certain constructs are more important in either low-intensity or highintensity networking firms could not be verified. One explanation is that we did not measure the importance of each variable individually; instead, we measured the combined effect of all the variables at once. Interaction effects between these variables could mask the individual effect of each construct.

It can be observed that, in most paths, an EO occurs in combination with an MD approach and vice versa (except for paths III and VII). Therefore, the combination of EO with MD seems to be crucial to achieve innovation success for both Solitudes and Networkers. In the majority of identified paths, EO and MD were found to be of high relevance for facilitating innovation success. EO plays a decisive role in each of the paths for Networkers, and in all but one of the paths for Solitudes (path III). MD is a precondition in all but one of the paths for Networkers (path VII) and in each of the paths for Solitudes. So, the assumption that EO occurs together with MD to achieve innovation success can be confirmed. 
Also, EO often occurs together with CO. Out of six paths in which $\mathrm{EO}$ has an impact on innovation success, it is combined with $\mathrm{CO}$ in three (paths I, VI, VII). CO always appears in combination with EO. These results span Solitudes and Networkers. Thus, to a large extent, the results confirm the strong interaction between EO and $\mathrm{CO}$ when it comes to successfully launching innovations.

A combination of EO with SO was found in two paths (II and V). However, EO exists without SO in three paths (I, IV, and VI). These results apply to Networkers as well as Solitudes. There is even one path (VII) where Networkers successfully innovate when EO is combined with purposefully neglecting SO. For Solitudes, there is one path (III) where SO exists without EO. Overall, the assumption that SO needs to be combined with EO to achieve innovation success could not be confirmed. Also, the assumption that SO needs $\mathrm{CO}$ to be successful could not be confirmed either. A combination of both strategic orientations could not be found in any path. In fact, in path VII, CO works best under the absence of SO.

Furthermore, our results did not confirm the assumption that RL needs EO to achieve innovation success. A combination of both was found in path IV (Networkers). Otherwise, EO either works best under the absence of RL (paths I and VII) or RL has no impact (paths II, V, VI). In one path (III), RL leads to innovation success and EO has no impact. Also, against our assumption, RL does not have to be combined with CO to innovate successfully. In fact, these two variables do not appear together in any path. On the contrary, in paths I and VII, CO works best in the absence of RL.

Still, multi-variable effects could have masked bi-variable effects in our study. What is evident, however, is that none of the examined strategic orientations and resource-leveraging capabilities are present in all six paths. Therefore, each strategic orientation needs to be combined with at least one other condition to achieve innovation success. This applies to Solitudes and Networkers alike.

\subsection{Managerial implications}

For practitioners, this study reveals the important finding that, for SMEs, innovation success is not about networking alone, but about underlying strategic orientations and resource-leveraging capabilities. Still, successful combinations of these depend on the SMEs' networking intensity.

Also, managers are well-advised not to rely on a single strategic orientation. In contrast to previous studies, this study does not recommend applying a certain strategic orientation, but rather, suggests combining different orientations in a unique way. Each construct is relevant for innovation success under certain conditions. Also, the combination of EO with MD and the finding that $\mathrm{CO}$ needs to be paired with EO serve as good starting points. However, these strategic orientations alone do not produce the desired outcome. As is evident, unique combinations of strategic orientations and resource-leveraging capabilities are necessary to promote innovation success.

\subsection{Limitations and future research}

Like all empirical studies, this study is also subject to a few limitations. The application of a key informant approach may have resulted in biased relationships between predictor and criterion variables (Podsakoff et al., 2003). A further limitation concerns a potential survivor bias. The sample of this study is composed of successful, or at least surviving, SMEs. However, strategic orientations such as EO may put companies in jeopardy due to high-risk strategies (Rauch et al., 2009). As a result, some SMEs failed because they adopted such a strategy. Due to the unattainability of failed SMEs, these firms are not considered in this study.

Originated in qualitative research, fsQCA is a technique that allows only a limited number of variables to be investigated for a sole outcome (Ragin, 2008). Consequently, more complex relationships between variables like multiple outcomes or grouping variables (moderators) can be investigated only by elaborate quantitative techniques, such as structural equation modeling (Jöreskog and Sörbom, 1982).

Since only a small amount of research analyzes several different strategic orientations-namely $\mathrm{EO}, \mathrm{CO}, \mathrm{MD}, \mathrm{SO}$, and the concept of RL within one study-future research could test whether distinctions exist between different industries and countries. Since this study treats all strategic orientations as unidimensional constructs, it would be interesting to investigate which aspects of the applied variables contribute to the achievement of innovation success to a greater or lesser extent. Also, it might be worthwhile to investigate other strategic orientations, such as learning, competitor, or technological orientation, since innovation success obviously depends not only on the constructs considered in this manuscript, but also on other factors that the innovating firm may or may not be able to control.

This study focuses on the examination of paths to innovation success being measured with a general variable. Therefore, it would be beneficial to differentiate between the various types of innovation, which can range from incremental to radical innovations, while taking potential differences between product or process innovation into account. To reveal which combinations of underlying strategic orientations lead to different innovation outputs, future research could be conducted.

As is evident from our study, the achievement of innovation success is neither dependent on the networking intensity of the SME nor on a single strategic orientation. However, this study demonstrates that lowand high-intensity networking firms require different combinations of strategic orientations and resource-leveraging capabilities to generate innovation success. This study assumed that firms that create and launch innovations successfully often grow and, in turn, contribute to societal wealth. Whereas all seven paths as revealed through our analysis lead to innovation success, Cocky Innovators (path VII) achieve this goal by purposefully ignoring social needs. Thus, further research is needed to investigate what types of innovation truly lead to societal wealth.

\section{References}

Abell, D., 1993. Managing with Dual Strategies. Free Press, New York.

Ahuja, G., 2000. The dualty of collaboration. inducements and opportunities in the formation of interfirm linkages. Strateg. Manag. J. 21 (3), 317-344.

Alguezaui, S., Filieri, R., 2010. Investigating the role of social capital in innovation: sparse versus dense network. J. Knowl. Manag. 14 (6), 891-909.

Anderson, B.S., Kreiser, P.M., Kuratko, D.F., Hornsby, J.S., Eshima, Y., 2015. Reconceptualizing entrepreneurial orientation. Strateg. Manag. J. 36 (10), 1579-1596.

Andersson, L., Jackson, S.E., Russell, S.V., 2013. Greening organizational behavior: an introduction to the special issue. J. Organ. Behav. 34 (2), 151-155.

Arias, J.T.G., 1995. Do networks really foster innovation? Manag. Decis. 33 (9), 52-56.

Armstrong, J.S., Overton, T.S., 1977. Estimating nonresponse bias in mail surveys. J. Mar. Res. 14 (3), 396-402.

Baker, W.E., Sinkula, J.M., 2009. The complementary effects of market orientation and entrepreneurial orientation on profitability in small businesses. J. Small Bus. Manag. 47 (4), 443-464.

Berthon, P., Hulbert, J.M., Pitt, L.F., 1999. To serve or create? strategic orientations toward customers and innovation. Calif. Manag. Rev. 42 (1), 37-58.

Bhidé, A.V., 2000. The Origin and Evolution of New Businesses. Oxford University Press, Oxford.

Carpenter, G.S., Glazer, R., Nakamoto, K., 2001. Market-Driving Strategies: Toward a New Concept of Competitive Advantage. Kellogg on Marketing. John Wiley \& Sons, New York, pp. 103-129.

Christensen, C., Bower, J., 1996. Customer power, strategic investment, and the failure of leading firms. Strateg. Manag. J. 17 (3), 197-218.

Cohen, W., Levinthal, D., 1990. Absorptive capacity: a new perspective on learning and innovation. Adm. Sci. Q. 35 (2), 128-152.

Covin, J.G., Lumpkin, G.T., 2011. Entrepreneurial orientation theory and research: reflections on a needed construct. Enterp. Theory Pract. 35 (5), 855-872.

Covin, J.G., Slevin, D.P., 1991. A conceptual model of entrepreneurship as firm behaviour. Enterp. Theory Pract. 16 (1), 7-24.

Covin, J.G., Wales, W.J., 2012. The measurement of entrepreneurial orientation. Enterp. Theory Pract. 36 (4), 677-702.

Covin, J.G., Eggers, F., Kraus, S., Cheng, C.-F., Chang, M.-L., 2016. Marketing-related resources and radical innovativeness in family and non-family firms: a configurational approach. J. Bus. Res. 69 (12), 5620-5627.

Crucke, S., Decramer, A., 2016. The development of a measurement instrument for the 
organizational performance of social enterprises. Sustainability 8 (2), 161

Day, G.S., 1999. Misconceptions about market orientation. J. Mark.-Focus. Manag. 4 (1), 5-16.

DeCoster, J., Iselin, A.-M.R., Gallucci, M., 2009. A conceptual and empirical examination of justifications for dichotomization. Psychol. Methods 14 (4), 349.

Eggers, F., Kraus, S., Hughes, M., Laraway, S., Snycerski, S., 2013. Implications of customer and entrepreneurial orientations for sme growth. Manag. Decis. 51 (3), 524-546.

Eggers, F., Kraus, S., Covin, J., 2014. Traveling into unexplored territory: pioneering innovativeness and the role of networking, customers, and Turbulent Environments. Ind. Mark. Manag. 43 (8), 1385-1393.

Freel, M.S., 2003. Sectoral patterns of small firm innovation, networking and proximity. Res. Policy 32 (5), 751-770.

Freeman, C., Soete, L., 1997. The Economics of Industrial Innovation. Psychology Press.

Frenken, K., 2000. A complexity approach to innovation networks. The case of the aircraft industry (1909-1997). Res. Policy 29 (2), 257-272.

Garnsey, E., Wilkinson, M., 1994. Global alliance in high technology: a trap for the unwary. Long Range Plan. 27 (6), 137-146.

Gemünden, H.G., Heydebreck, P., Herden, R., 1992. Technological interweavement: a means of achieving innovation success. R D Manag. 22 (4), 359-376.

Gemünden, H.G., Ritter, T., Heydebreck, P., 1996. Network configuration and innovation success: an empirical analysis in german high-tech industries. Int. J. Res. Mark. 13 (5), 449-462.

Gronum, S., Verreynne, M.L., Kastelle, T., 2012. The role of networks in small and medium-sized enterprise innovation and firm performance. J. Small Bus. Manag. 50 (2), 257-282.

Hagedoorn, J., 1995. Strategic technology partnering during the 1980s: trends, networks and corporate patterns in non-core technologies. Res. Policy 24 (2), 207-231.

Halberstadt, J., Kraus, S., 2016. Social entrepreneurship: the foundation of tomorrow's commercial business models? Int. J. Ent. Vent. 8 (3), 261-279.

Hamel, G., Prahalad, C.K., 1994. Competing for the Future. Harvard Business School Press, Boston.

Harris, L., Coles, A.-M., Dickson, K., 2000. Building innovation networks: issues of strategy and expertise. Tech. Anal. Strat. Manag. 12 (2), 229-241.

Heunks, F.J., 1998. Innovation, creativity and success. Small Bus. Econ. 10 (3), 263-272.

Jarillo, J.C., 1989. Entrepreneurship and growth: the strategic use of external resources. J. Bus. Ventur. 4 (2), 133-148.

Jaworski, B., Kohli, A.K., Sahay, A., 2000. Market-driven versus driving markets. J. Acad. Mark. Sci. 28 (1), 45-54.

Jöreskog, K.G., Sörbom, D., 1982. Recent Developments in Structural Equation Modeling. J. Mar. Res. 19 (4), 404-416.

Kline, R.B., 2015. Principles and Practice of Structural Equation Modeling. Guilford Press, New York, NY.

Kraus, S., Niemand, T., Halberstadt, J., Shaw, E., Syrjä, P., 2017. Social entrepreneurship orientation: development of a measurement scale. Int. J. Ent. Behav. Res. 23 (6), 977-997.

Kraus, S., Ribeiro-Soriano, D., Schüssler, M., 2018. Fuzzy-set qualitative comparative analysis (fsQCA) in entrepreneurship and innovation research - the rise of a method. Int. Entrep. Manag. J. 14 (1), 15-33.

Kumar, N., Scheer, L., Kotler, P., 2000. From market driven to market driving. Eur. Manag. J. 18 (2), 129-142.

Leadbeater, C., 1997. The Rise of the Social Entrepreneur. Demos.

Lee, C., Lee, K., Pennings, J.M., 2001. Internal capabilities, external networks, and performance: a study on technology-based ventures. Strateg. Manag. J. 22 (6/7), $615-640$.

Love, J.H., Roper, S., 1999. The determinants of innovation: R \& D, technology transfer and networking effects. Rev. Ind. Organ. 15 (1), 43-64.

Lumpkin, G.T., Dess, G.G., 1996. Clarifying the entrepreneurial orientation construct and linking it to performance. Acad. Manag. Rev. 21 (1), 135-172.

Miles, M.P., Verreynne, M.-L., Luke, B., 2014. Social enterprises and the performance advantages of a vincentian marketing orientation. J. Bus. Ethics 123 (4), 549-556.

Miller, D., 1983. The correlates of entrepreneurship in three types of firms. Manag. Sci. 29 (7), 770-791.

Miller, D., Friesen, P., 1978. Archetypes of strategy formulation. Manag. Sci. 24 (9), 921-933.

Morris, M.H., Schindehutte, M., LaForge, R.W., 2002. Entrepreneurial marketing: a construct for integrating emerging entrepreneurship and marketing perspectives. J. Mark. Theory Pract. 10 (4), 1-19.

Mulgan, G., Tucker, S., Ali, R., Sanders, B., 2007. Social Innovation: What It Is, Why It Matters and How It Can Be Accelerated. Saïd Business School, Oxford.

Narver, J.C., Slater, S.F., MacLachlan, D.L., 2004. Responsive and proactive market orientation and new-product success. J. Prod. Innov. Manag. 21 (5), 334-347.

OECD, 2010. The Oecd Innovation Strategy: Getting a Head Start on Tomorrow. OECD Pub.

Ostgaard, T.A., Birley, S., 1994. Personal networks and firm competitive strategy-a strategic or coincidental match? J. Bus. Ventur. 9 (4), 281-305.

Pittaway, L., Robertson, M., Munir, K., Denyer, D., Neely, A., 2004. Networking and innovation: a systematic review of the evidence. Int. J. Manag. Rev. 5 (3-4), 137-168.

Podsakoff, P.M., MacKenzie, S.B., Lee, J.-Y., Podsakoff, N.P., 2003. Common method biases in behavioral research: a critical review of the literature and recommended remedies. J. Appl. Psychol. 88 (5), 879-903.

Powell, W.W., Koput, K.W., Smith-Doerr, L., 1996. Interorganizational collaboration and the locus of innovation: networks of learning in biotechnology. Adm. Sci. Q. 41 (1), 116-145.

Ragatz, G.L., Handfield, R.B., Scannell, T.V., 1997. Success factors for integrating suppliers into new product development. J. Prod. Innov. Manag. 14 (3), 190-202.
Ragin, C.C., 2008. Redesigning Social Inquiry: Fuzzy Sets and Beyond. Chicago University Press, Chicago.

Rauch, A., Wiklund, J., Lumpkin, G., Frese, M., 2009. Entrepreneurial orientation and business performance: an assessment of past research and suggestions for the future. Enterp. Theory Pract. 33 (3), 761-787.

Rigtering, C., Kraus, S., Eggers, F., Jensen, S.H., 2014. A comparative analysis of the entrepreneurial orientation/growth relationship in service firms and manufacturing firms. Serv. Ind. J. 34 (4), 275-294.

Ritter, T., Gemünden, H.G., 2003. Network competence: its impact on innovation success and its antecedents. J. Bus. Res. 56 (9), 745-755.

Robinson, J., 2006. Navigating Social and Institutional Barriers to Markets: How Social Entrepreneurs Identify and Evaluate Opportunities (Ed.), Social Entrepreneurship. Springer, pp. 95-120.

Rogers, M., 2004. Networks, firm size and innovations. Small Bus. Econ. 22 (2), 141-153.

Schindehutte, M., Morris, M.H., Kocak, A., 2008. Understanding market-driving behavior: the role of entrepreneurship. J. Small Bus. Manag. 46 (1), 4-26.

Semrau, T., Ambos, T.C., Kraus, S., 2016. Entrepreneurial orientation and sme performance across societal cultures. J. Bus. Res. 69 (5), 1928-1932.

Sharir, M., Lerner, M., 2006. Gauging the success of social ventures initiated by individual social entrepreneurs. J. World Bus. 41 (1), 6-20.

Shaw, E., Carter, S., 2007. Social entrepreneurship: theoretical antecedents and empirical analysis of entrepreneurial processes and outcomes. J. Small Bus. Ent. Dev. 14 (3), 418-434.

Sirmon, D.G., Hitt, M.A., Ireland, R.D., 2007. Managing firm resources in dynamic environments to create value: looking inside the black box. Acad. Manag. Rev. 32 (1), 273-292.

Skarmeas, D., Leonidou, C.N., Saridakis, C., 2014. Examining the role of Csr skepticism using fuzzy-set qualitative comparative analysis. J. Bus. Res. 67 (9), 1796-1805.

Slater, S.F., Narver, J.C., 1998. Customer-led and market-oriented - let's not confuse the two. Strateg. Manag. J. 19 (10), 1001-1006.

Stolper, M., 2007. Market Driving-Konzept: Modellierung Und Empirische Prüfung Von Erfolg Und Erfolgsfaktoren. GWV Fachverlag GmbH, Wiesbaden.

Thiem, A., Dusa, A., 2013. Qca: a package for qualitative comparative analysis. R J. 5 (1), 87-97.

Verhees, F.J., Meulenberg, M.T., 2004. Market orientation, innovativeness, produkt innovation, and performance in small firms. J. Small Bus. Manag. 42 (2), 134-154.

Von Hippel, E., 1978. Successful industrial products from customer ideas. J. Mark. 42 (1), 39-49.

Wagemann, C., Schneider, C.Q., 2010. Qualitative comparative analysis (Qca) and fuzzysets: agenda for a research approach and a data analysis technique. Comp. Sociol. 9 (3), 376-396.

Wales, W.J., Gupta, V.K., Mousa, F.-T., 2013. Empirical research on entrepreneurial orientation: an assessment and suggestions for future research. Int. Small Bus. J. 31 (4), 357-383.

Walter, A., Auer, M., Ritter, T., 2006. The impact of network capabilities and entrepreneurial orientation on university spin-off performance. J. Bus. Ventur. 21 (4), $541-567$.

Wiklund, J., Shepherd, D., 2005. Entrepreneurial orientation and small business performance: a configuration approach. J. Bus. Ventur. 20 (1), 71-91.

Wilson, H.I., Appiah-Kubi, K., 2002. Resource leveraging via networks by high-tech nology entrepreneurial firms. J. High Technol. Managem. Res. 13 (1), 45-62.

Woodside, A.G., 2013. Moving beyond multiple regression analysis to algorithms: calling for adoption of a paradigm shift from symmetric to asymmetric thinking in data analysis and crafting theory. J. Bus. Res. 66 (4), 463-472.

Zortea-Johnston, E., Darroch, J., Matear, S., 2012. Business orientations and innovation in small and medium sized enterprises. Int. Entrep. Manag. J. 8 (2), 145-164.

Fabian Eggers is an Associate Professor of Marketing and Entrepreneurship at Menlo College. Prior to joining Menlo, he worked as Visiting Professor at San Jose State University. Fabian received his Ph.D. (Management/Marketing) from the University of Lüneburg, Germany. His research focuses on Entrepreneurial Marketing and Innovation Management as drivers of Strategic Marketing decisions. Fabian Eggers is Director of the Global Research Symposium on Marketing and Entrepreneurship.

Thomas Niemand is an Associate Professor of Management and Market Research at the University of Technology Clausthal, Germany. He holds a PhD in Marketing and Management from the University of Technology Dresden, Germany. His research focuses on marketing, entrepreneurship and innovation. His work has been published widely in leading academic and professional journals such as the Journal of Product Innovation Management, Journal of Business Research, Journal of Interactive Marketing, Journal of Small Business Management and Review of Managerial Science.

Matthias Filser is an Assistant Professor at the University of Liechtenstein, where he is deputy academic and executive director of the master's degree program in Entrepreneurship. In November 2013, he received his Ph.D. from Utrecht University, the Netherlands. His research focuses on strategic entrepreneurship, family business, and innovation. His work has been published widely in leading academic and professional journals such as the British Journal of Management, Journal of Business Ethics, Journal of Business Research, Journal of Product Innovation Management and Journal of Small Business Management.

Sascha Kraus is a Research Professor for Innovation \& Entrepreneurship at ESCE International Business School, Paris, France. Before, he was a Full Professor and Chairholder in Strategic Management and Entrepreneurship at the University of Liechtenstein, and, parallel to that, Visiting Professor at Copenhagen Business School, 
Denmark in 2015 and at the University of St. Gallen, Switzerland in the two years before. He holds a doctorate in Social and Economic Sciences from Klagenfurt University, Austria, a Ph.D. degree in Industrial Engineering and Management from Helsinki University of Technology and a Habilitation (Venia Docendi) from Laapeenranta University of Technology, both in Finland.
Jennifer Berchtold is a $\mathrm{PhD}$ candidate in Economics and Business Administration at Lappeenranta University of Technology, Finland. She holds a Master of Science in Strategic Management from University of Innsbruck and received her Bachelor of Science in Business Administration from University of Liechtenstein. Her research interests focus on the concept of entrepreneurial orientation (EO). In particular, she is researching the relationship between EO and performance as well as the moderators and mediators of the EO-performance relationship. 